Thi-Qar Medical Journal (TQMJ): Vol.(15), No.(1), 2018

Web Site: https://jmed.utq.edu.iq $\quad$ Email:utjmed@utq.edu.iq

\title{
Predictability of consecutive measurements of serum Anti-Mullerian Hormone (AMH) during In Vitro Fertilization (IVF)
}

\author{
Saman Hussein Noori / MBChB, MSc, PhD Clinical Biochemistry \\ University of Sulaimani / College of Medicine / Department of Biochemistry
}

\begin{abstract}
Background : In recent years, many studies had been carried out on the basal AMH level and its association with controlled ovarian hyperstimulation $(\mathrm{COH})$ outcome. Only a few studies have been conducted on the correlation between $\mathrm{COH}$ outcomes and $\mathrm{AMH}$ levels measured on different stimulation days and these studies did not show a comparison between different measurement timings over the entire period of the $\mathrm{COH}$ cycle.
\end{abstract}

Objectives: the current study aim is to assess the predictive values of basal and consecutive serum $\mathrm{AMH}$ levels during $\mathrm{COH}$ cycle.

Methods and Results: One hundred women were involved in this study, scheduled for IVF program in Dwarozh Fertility Center in Sulaimanyiah, between December 2015 until January 2017, blood samples were collected for measurement of AMH, Estradiol, and FSH on day 2 of menstrual cycle, and the subsequent samples on day 4,6,8 and 10 were taking after the stimulation of ovaries with gonadotrophin. All hormones being analyzed by using electrochemiluminescence methods (Cobas 411 by Roche) as a single batch, each patient was given a unique numerical identifier, which issued in data analysis. $\mathrm{P}$ values $<0.05$ were considered significant.

Results: the patients' characteristics, basal serum estradiol (E2), FSH and AMH levels at day 2 of cycle and subsequent days after stimulation. As expected significant differences were observed for total dosage of FSH, peak E2 levels and duration of stimulation between short and long GnRH agonist groups. The ROC curve was used to assess the AMH values in different days (day 2, 4, 6, 8, and 10) for prediction of IVF outcomes (implantation, abortion, preganancy and live birth). All the days showed significant area under the curve (AUC) $(\mathrm{p}<0.05)$. However, when all the ROC curve were comapred to each others there were no significance differences bwteeen them $(p>0.05)$

Conclusions: The present study concluded that measurement of serum AMH at any time after stimulation still predictive of the IVF outcomes which will reinforce the already known value of $\mathrm{AMH}$ in clinical practice. 


\section{Introduction}

Anti-Mullerian hormone (AMH) is a member of the transforming growth factor- $\beta$ superfamily (1). Recently, it has been suggest that AMH acts as direct biochemical marker of ovarian reserve as well as a regulator of folliculogenesis and oocyte maturation (2).

Many studies had been carried out on the basal AMH level and its association with controlled ovarian hyperstimulation $(\mathrm{COH})$ outcome. It has been shown that the basal AMH level is correlated with antral follicle count (AFC), total dose of gonadotrophins used, duration of $\mathrm{COH}$, estradiol level on hCG day, the number of mature follicles on hCG day and the number of oocytes retrieved (3-5). Moreover, the AMH level was found to be positively related to pregnancy in $\mathrm{COH}$ cycles $(6,7)$. It had been also suggested that the serum AMH level could predict poor response and ovarian hyperstimulation syndrome for IVF cycles (8, 9). Serum AMH levels show no fluctuation throughout the menstrual cycle, and the AMH level had been shown to be correlate with ovarian response to gonadotrophin stimulation independent of the days of the menstrual cycle $(8,10)$.

Several provocative tests had been developed to indirectly assess ovarian reserve and identify patients who might not be define by basal hormone screening alone. However, whether these indirect provocative tests are more informative of ovarian reserve than basal hormone remains controversial. Furthermore, neither basal hormonal measurements nor those dynamic tests are capable of providing direct manifestation concerning the outcomes of the exogenous gonadotropin used in ovarian stimulation for ART (11$15)$.

To clarify these issues, studies had been perform on changes in serum $\mathrm{AMH}$ levels during $\mathrm{COH}$ cycle, however; most of these studies were conducted only during GnRH agonist cycles and either follicular or luteal phases of the $\mathrm{COH}$ cycle (16-20). To the best of our knowledge, there were no studies on $\mathrm{AMH}$ changes over the entire $\mathrm{COH}$ period, including days before human chorionic gonadotrophin (HCG) administration, and during $\mathrm{GnRH}$ antagonist cycles. Therefore, the current study aim is to assess the predictive values of basal and consecutive serum AMH level during IVF stimulation.

Serum AMH levels show no fluctuation throughout the menstrual cycle, and the AMH level had been shown to be correlate with ovarian response to gonadotrophin stimulation independent of the days of the menstrual cycle $(8,10)$. In another study, using different 
measurement timing, the $\mathrm{AMH}$ levels during the menstrual cycle showed a correlation with the outcomes similar to that observed following $\mathrm{COH}$ cycles (21). However, during $\mathrm{COH}$ cycles, the serum AMH level changes throughout the cycle; thus, this correlation with $\mathrm{COH}$ outcomes could depend on the timing of the measurement. Only a few studies have been conducted on the correlation between $\mathrm{COH}$ outcomes and AMH levels measured on different stimulation days $(16,22$, 23 ), and these studies did not show a comparison between different measurement timings over the entire period of the $\mathrm{COH}$ cycle. Therefore, the current study aim is to assess the predictive values of basal and consecutive serum AMH levels during $\mathrm{COH}$ cycle.

\section{Material and methods}

One hundred women were involved in this cohort study, scheduled for IVF program, between December 2015 until January 2017, blood samples were collected for measurement of AMH, Estradiol, and FSH on day 2 of menstrual cycle, and the subsequent samples on day 4,6,8 and 10 were taking after the stimulation of ovaries with gonadotrophin.

Venous blood samples (5-10ml) were collected in tubes containing no anticoagulant. Samples were allowed to clot at $37^{\circ} \mathrm{C}$; then centrifuged at $3000 \mathrm{rpm}$ for more than10 minutes to separate the cellular component. Sera were removed and stored in aliquots at $20 \mathrm{C}$ until analyses. Lipemic or hemolyzed samples were eliminated. All hormones being analyzed by using electrochemiluminescence methods (Cobas 411 by Roche) as a single batch, each patient was given a unique numerical identifier, which issued in data analysis.

Written consent for the treatment by IVF/ICSI and enrollment for research were taken from each patient, inclusion criteria were a patient age under 46 years, normal pretreatment hormonal values, presence of two ovaries, gynecological ultrasound results, and cervical smears. The exclusion criteria included none of the women had received sex steroids or any drug known to affect ovarian function for at least 6 months, no previous ovarian surgery, acute or chronic infectious diseases of the woman or her partner, severe psychiatric illnesses, no endocrine abnormalities including hyperprolactinaemia or the presence of other concomitant chronic conditions such as genetic syndromes, celiac disease, renal disease, liver disease, thyroid disorder, diabetic mellitus, cancer, ischemic heart diseases, nephrotic 
syndrome they were not included and excluded from the current study. Menstrual cycles were consider as irregular if they were longer than 35 days or shorter than 25 days or when the length difference between two successive cycles was greater than 7 days.

\section{Statistical analysis:}

Data is translate into codes using a specially designed coding sheet, and then converted to computerized database. An expert statistical advice was taken and statistical analyses were done using SPSS (Statistical Package for Social Science) (version 19 Chicago, USA) and MedCalc (version 12.2.1.0, Mariakerke, Belgium) computer software. The variables were assessed by the chi square test, D'Agostino-Pearson and Kolmogorov-Smirnov test for normal distribution. The receiver operative characteristic (ROC) curve was use for predicting the IVF outcomes paired $\mathrm{T}$ test was use for comparing two variables. $\mathrm{P}$ values $<0.05$ were considered significant.

\section{Results}

The frequency distribution, Kolmogorov-Simirnov test and D'Agostino-Pearson test of all the variables show that they were normally distributed $(\mathrm{P}<0.05)$ (data not shown), therefore parametrical methods were applied for subsequent statistical analyses.

Table 1 showed the patients' characteristics , basal serum estradiol (E2), FSH and AMH levels at day 2 of cycle and subsequent days after stimulation. As expected significant differences were observed for total dosage of FSH, peak E2 levels and duration of stimulation between short and long $\mathrm{GnRH}$ agonist groups

The reciver operative charactertic (ROC) curve was used to assess the AMH values in different days (day $2,4,6,8$, and 10) for predction of IVF outcomes (implantation, abortion, preganancy and live birth). All the days showed significant area under the curve (AUC) $(\mathrm{p}<0.05)$ figures 1 to 4 . However, when all the ROC curves were comapred to each other there were no significance differences bwteeen them $(p>0.05)$ tables 2 to 5 .

\section{Discussion}

In recent years, many studies had been performing on the basal AMH level and its association with $\mathrm{COH}$ outcomes. Only few studies have been conducted on the correlation between $\mathrm{COH}$ outcomes and $\mathrm{AMH}$ levels measured on different stimulation days $(16,22,23)$. However, these studies neither show a comparison between different measurement timings of serum AMH over the entire period of the 
$\mathrm{COH}$ cycle nor timing effectiveness on IVF outcomes.

The present study results showed no significant changes in serum $\mathrm{AMH}$ at basal and subsequent days after stimulation and that serum AMH levels significantly predict $(\mathrm{P}<0.05)$ the IVF outcomes (implantation, abortion, preganancy and live birth) at basal and sequential measurements after gonadotrophin stimulation. Data available in the literature with respect to this issue are limited. The current study results are in keeping with the results of Eldar-Geva1T. et al study who found that early follicular and mid-luteal serum AMH levels were very similar (17) as well as in agreement with Elgindy E. A et al. study, by using different measurement timing, found that the midluteal and early AMH levels were statistically significant predictors of clinical pregnancy (21). Even so, the present study results diverge from preliminary data reported by others $(17,19)$ that showed decline in serum AMH levels during $\mathrm{COH}$ cycles.

The sources of conflict between these studies and the present study may include characteristics of the study population, variations in the study design, and differences of statistical methods as well as the smaller sample sizes used by previous studies, which may affect the accuracy of their results. Another factor that might be involved in the ontogenesis of AMH is different stimulation protocols used in each study.

The present study concluded that measurement of serum AMH at any time after stimulation still predictive of the IVF outcomes, which will reinforce the already known value of AMH in clinical practice. Moreover, this new finding may resolved missed basal AMH measurement due to any various reasons and will be more convenient to the patient and the clinician 
Thi-Qar Medical Journal (TQMJ): Vol.(15), No.(1), 2018

Web Site: https://jmed.utq.edu.iq $\quad$ Email:utjmed@utq.edu.iq

\begin{tabular}{|l|l|l|l|}
\hline Variables & $\begin{array}{l}\text { Short GnRH } \\
\text { agonist }(n=77)\end{array}$ & $\begin{array}{l}\text { Long GnRH } \\
\text { Agonist }(\mathbf{n}=23)\end{array}$ & P-value \\
\hline
\end{tabular}

Table 1: Clinical and biochemical characteristics of the study patients 
Thi-Qar Medical Journal (TQMJ): Vol.(15), No.(1), 2018 Web Site: https://jmed.utq.edu.iq Email:utjmed@utq.edu.iq

\begin{tabular}{|c|c|c|c|}
\hline Age (years) & $36.23 \pm 7.0$ & $35.50 \pm 6.93$ & 0.66 \\
\hline BMI (kg/m2) & $25 \pm 3$ & $26 \pm 2$ & 0.13 \\
\hline Estradiol (pg/ml) & $44.02 \pm 30.51$ & $35.26 \pm 18.55$ & 0.19 \\
\hline FSH (IU/I) & $8.57 \pm 3.36$ & $6.45 \pm 3.62$ & 0.01 \\
\hline AMH Day 2 (ng/ml) & $2.01 \pm 1.67$ & $1.75 \pm 1.27$ & 0.49 \\
\hline $\begin{array}{l}\text { Duration of infertility } \\
\text { (years) }\end{array}$ & $8.85 \pm 5.19$ & $10.62 \pm 7.69$ & 0.07 \\
\hline \multicolumn{4}{|l|}{ Types of infertility } \\
\hline Primary infertility & $65(84.4 \%)$ & $19(82.6) \%$ & 0.8 \\
\hline Secondary infertility & $12(15.6 \%)$ & $4(17.3 \%)$ & 0.85 \\
\hline \multicolumn{4}{|l|}{ Cause of infertility } \\
\hline Male factor & $5(6.5 \%)$ & $2(7.1 \%)$ & 0.72 \\
\hline Female factor & $10(12.9 \%)$ & $2(7.1 \%)$ & 0.73 \\
\hline Male and female factor & $53(68.8 \%)$ & $17(78.6 \%)$ & 0.6 \\
\hline Unexplained factor & $9(11.7 \%)$ & $2(7.1 \%)$ & 0.89 \\
\hline \multicolumn{4}{|l|}{ IVF outcomes } \\
\hline $\begin{array}{l}\text { Duration of stimulation } \\
\text { (days) }\end{array}$ & $11.20 \pm 0.96$ & $9.29 \pm 5.08$ & 0.002 \\
\hline Total dosage of FSH (IU) & $2924.22 \pm 986.51$ & $3369.64 \pm 1203.77$ & 0.07 \\
\hline Peak estradiol (pg/ml) & $1554.88 \pm 933.74$ & $937.96 \pm 758.49$ & 0.004 \\
\hline Implantation & $65(84.3 \%)$ & $19(82.6 \%)$ & 0.75 \\
\hline Clinical pregnancy & $15(20.3 \%)$ & $8(34.7 \%)$ & 0.85 \\
\hline Live birth & $8(10.9 \%)$ & $3(13.1 \%)$ & 0.33 \\
\hline Abortion & $7(9 \%)$ & $5(21.7 \%)$ & 0.79 \\
\hline AMH (ng/ml) Day 4 & $2.1 \pm 1.63$ & $1.77 \pm 1.3$ & 0.37 \\
\hline AMH (ng/ml) Day 6 & $2.01 \pm 1.56$ & $1.64 \pm 1.76$ & 0.33 \\
\hline AMH (ng/ml) Day 8 & $2.07 \pm 1.55$ & $1.89 \pm 2.3$ & 0.66 \\
\hline AMH (ng/ml) Day 10 & $2.05 \pm 1.54$ & $1.91 \pm 2.1$ & 0.72 \\
\hline
\end{tabular}




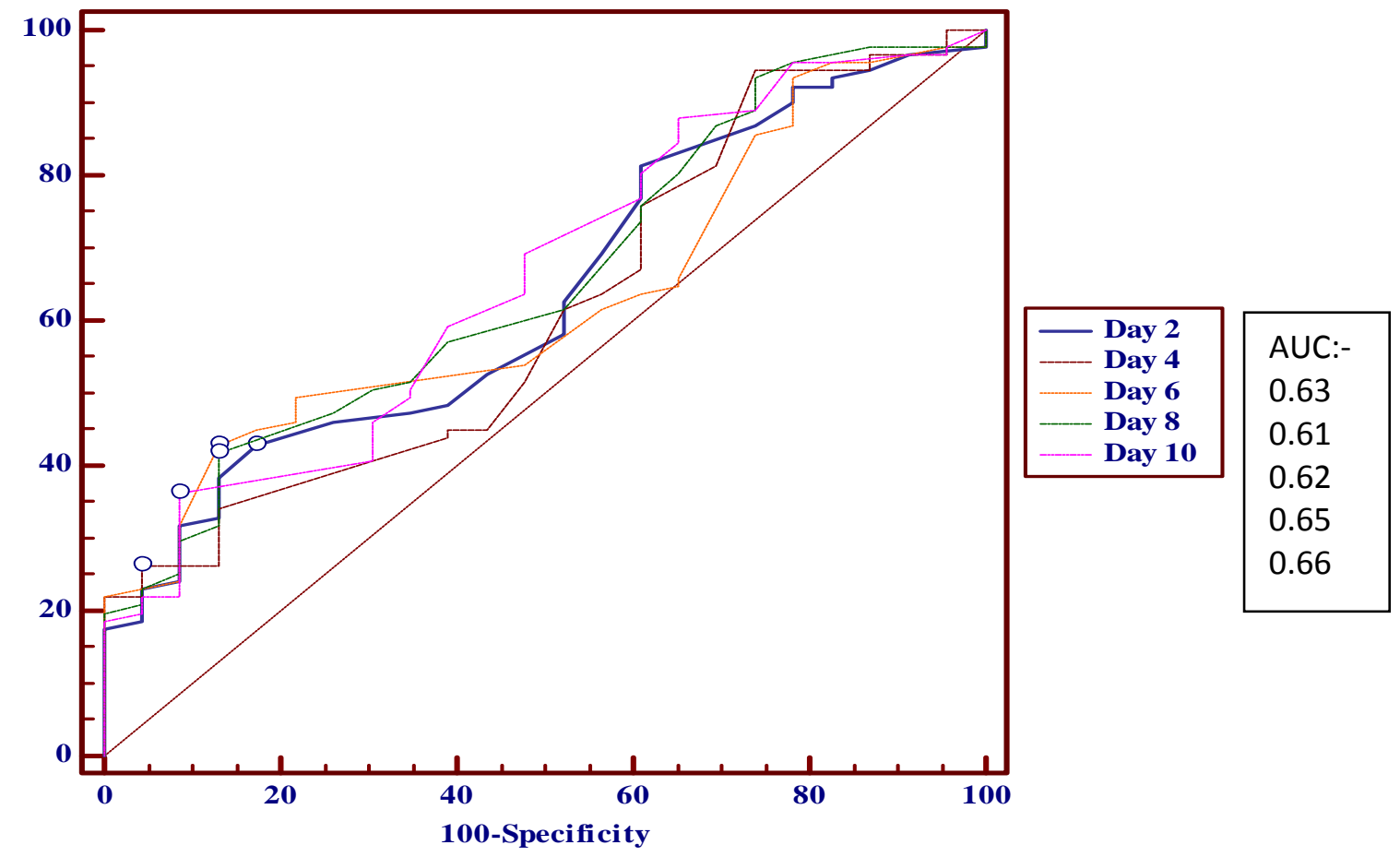

Figure 1: ROC curve of AMH value of different days in prediction of implantation.

Table 2: Pairwise comparison of various AMH ROC curves of different days in favor of implantation

\begin{tabular}{|c|c|c|}
\hline Paired ROC curves & Paired T test & P value \\
\hline Day 2 Vs Day 4 & 0.73 & 0.46 \\
\hline Day 2 Vs Day 6 & 0.27 & 0.78 \\
\hline Day 2 Vs Day 8 & 0.66 & 0.50 \\
\hline Day 2 Vs Day 10 & 0.60 & 0.54 \\
\hline Day 4 Vs Day 6 & 0.55 & 0.57 \\
\hline Day 4 Vs Day 8 & 1.4 & 0.13 \\
\hline Day 4 Vs Day 10 & 1.3 & 0.17 \\
\hline Day 6 Vs Day 8 & 1.7 & 0.08 \\
\hline Day 6 Vs Day 10 & 1.08 & 0.27 \\
\hline
\end{tabular}




\section{Day 8 Vs Day 10 \\ 0.90 \\ 0.90}

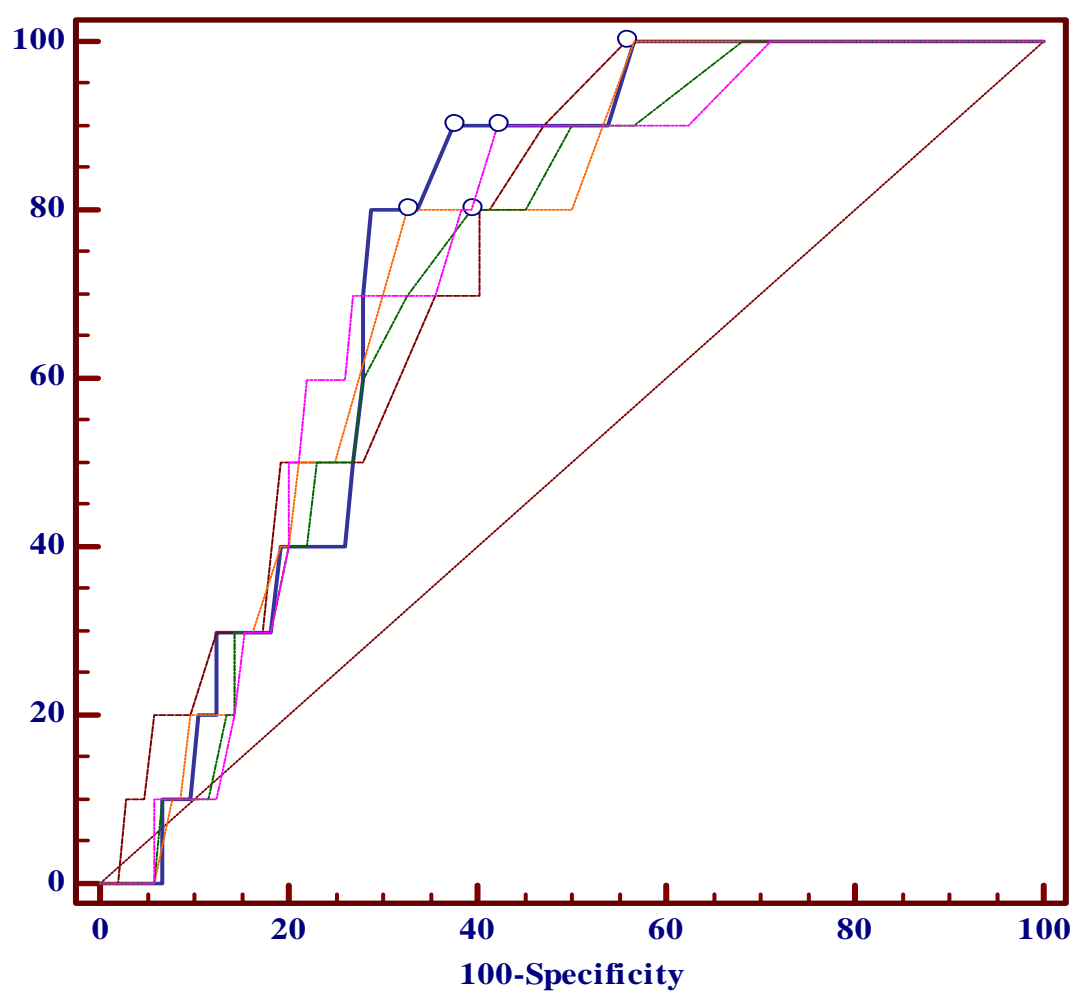

\begin{tabular}{|c||l|}
\hline - Day 2 & AUC:- \\
\hline Day 4 & 0.75 \\
Day 6 & 0.74 \\
\hline Day 8 & 0.73 \\
\hline Day 10 & 0.72 \\
& 0.73 \\
\hline
\end{tabular}

Figure 2: ROC curve of AMH value of different days in prediction of abortion.

Table 3: Pairwise comparison of various AMH ROC curves of different days in favor of abortion

\begin{tabular}{|c|c|c|}
\hline Paired ROC curves & Paired T test & P value \\
\hline Day 2 Vs Day 4 & 0.16 & 0.87 \\
\hline Day 2 Vs Day 6 & 0.59 & 0.54 \\
\hline Day 2 Vs Day 8 & 1.5 & 0.11 \\
\hline Day 2 Vs Day 10 & 0.43 & 0.66 \\
\hline Day 4 Vs Day 6 & 0.18 & 0.85 \\
\hline Day 4 Vs Day 8 & 0.67 & 0.50 \\
\hline Day 4 Vs Day 10 & 0.24 & 0.80 \\
\hline Day 6 Vs Day 8 & 1.15 & 0.24 \\
\hline Day 6 Vs Day 10 & 0.17 & 0.85 \\
\hline
\end{tabular}




\section{Day 8 Vs Day 10 \\ 0.38 \\ 0.69}

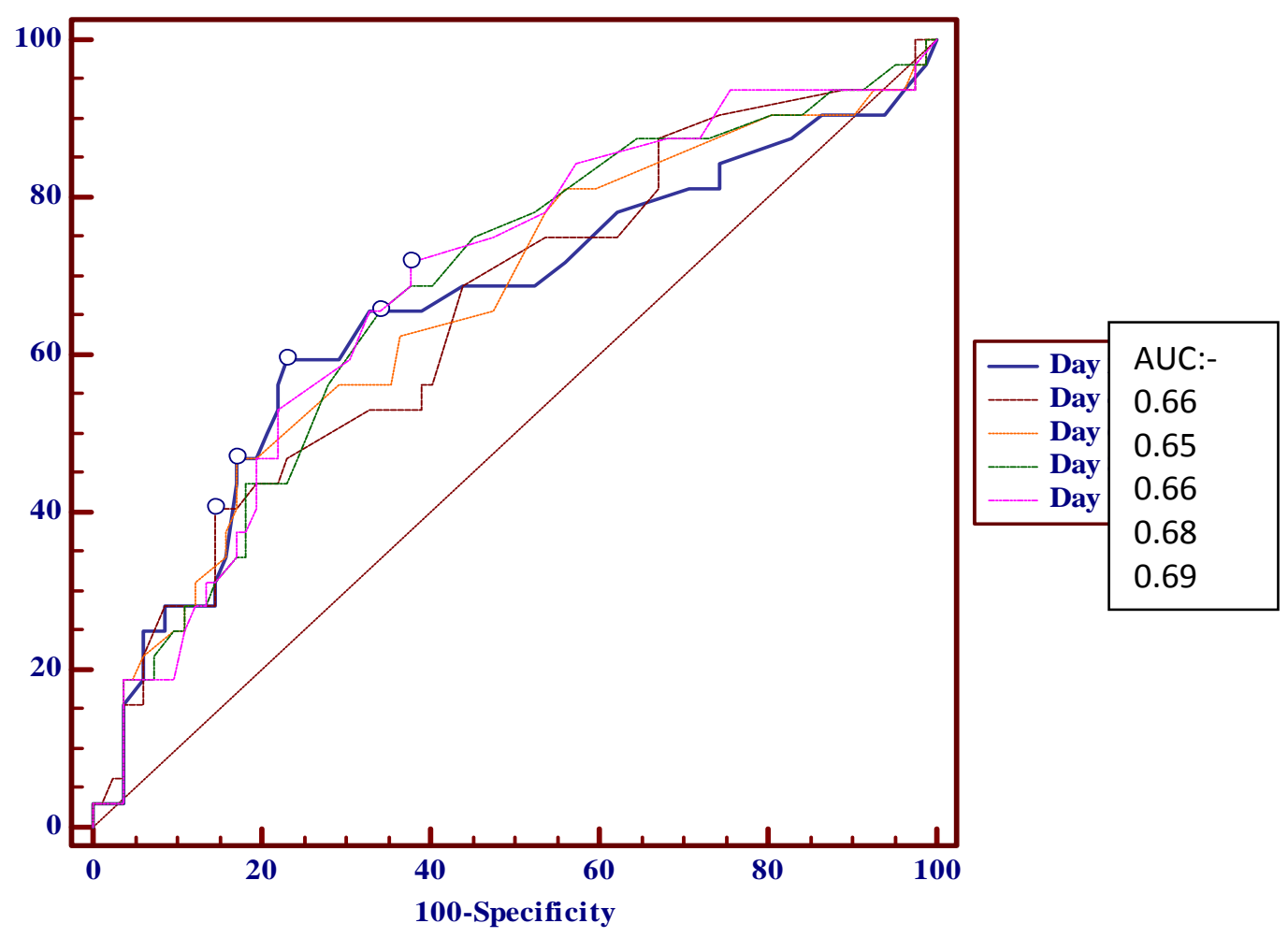

Figure 3: ROC curve of AMH value of different days in prediction of pregnancy.

Table 4: Pairwise comparison of various AMH ROC curve of different days in favor of pregnancy

\begin{tabular}{|c|c|c|}
\hline Paired ROC curves & Paired T test & P value \\
\hline Day 2 Vs Day 4 & 0.14 & 0.88 \\
\hline Day 2 Vs Day 6 & 0.26 & 0.79 \\
\hline Day 2 Vs Day 8 & 0.91 & 0.36 \\
\hline Day 2 Vs Day 10 & 1.02 & 0.30 \\
\hline Day 4 Vs Day 6 & 0.37 & 0.70 \\
\hline Day 4 Vs Day 8 & 0.88 & 0.37 \\
\hline Day 4 Vs Day 10 & 1.0 & 0.31 \\
\hline Day 6 Vs Day 8 & 1.1 & 0.26 \\
\hline Day 6 Vs Day 10 & 1.2 & 0.22 \\
\hline
\end{tabular}




\section{Day 8 Vs Day 10 \\ 0.5 \\ 0.60}

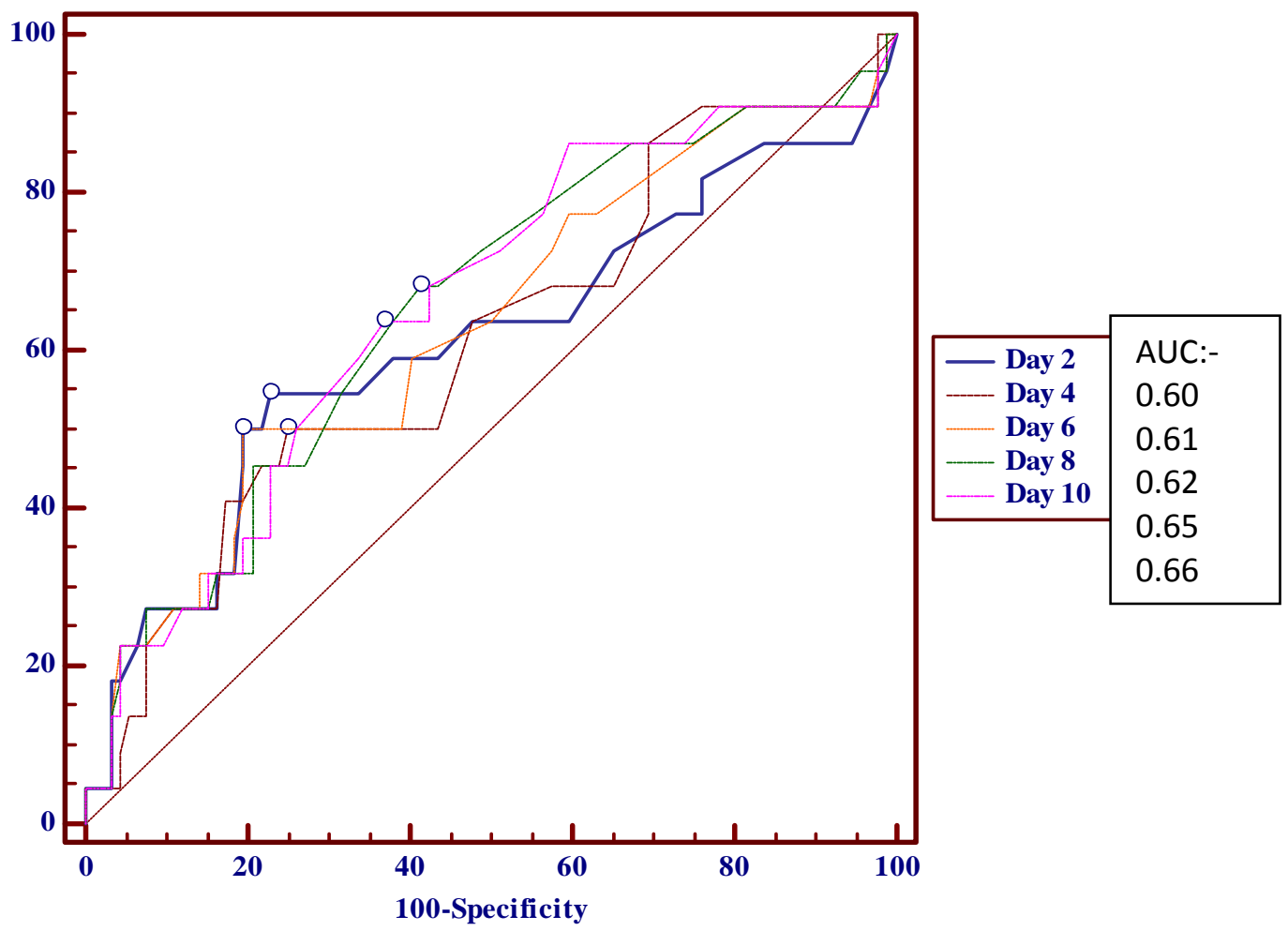

Figure 4: ROC curve of AMH value of different days in prediction of live birth.

Table 5: Pairwise comparison of various AMH ROC curve of different days in favor of live birth

\begin{tabular}{|c|c|c|}
\hline $\begin{array}{c}\text { Paired ROC } \\
\text { curves }\end{array}$ & Paired T test & P value \\
\hline Day 2 Vs Day 4 & 0.005 & 0.99 \\
\hline Day 2 Vs Day 6 & 0.7 & 0.44 \\
\hline Day 2 Vs Day 8 & 1.5 & 0.11 \\
\hline Day 2 Vs Day 10 & 1.3 & 0.18 \\
\hline Day 4 Vs Day 6 & 0.5 & 0.57 \\
\hline Day 4 Vs Day 8 & 1.17 & 0.23 \\
\hline Day 4 Vs Day 10 & 1.06 & 0.28 \\
\hline
\end{tabular}




\begin{tabular}{|c|c|c|}
\hline Day 6 Vs Day 8 & 1.47 & 0.14 \\
\hline Day 6 Vs Day 10 & 1.11 & 0.26 \\
\hline Day 8 Vs Day 10 & 0.03 & 0.97 \\
\hline
\end{tabular}

\section{References}

1. Dondik Y, Virji N, Butler TS, Gaskins JT, Pagidas K, Sung L. The Value of Anti-Mullerian Hormone in Predicting Clinical Pregnancy After Intrauterine Insemination. J Obstet Gynaecol Can. 2017 Jun 21.

2. Meczekalski B, Czyzyk A, Kunicki M, Podfigurna-Stopa A, Plociennik L, Jakiel G, et al. Fertility in women of late reproductive age: the role of serum anti-Mullerian hormone (AMH) levels in its assessment. J Endocrinol Invest. [Review]. 2016 Nov;39(11):1259-65.

3. Seifer DB, MacLaughlin DT, Christian BP, Feng B, Shelden RM. Early follicular serum mullerianinhibiting substance levels are associated with ovarian response during assisted reproductive technology cycles. Fertil Steril. [Comparative Study]. 2002 Mar;77(3):468-71.

4. van Rooij IA, Broekmans FJ, te Velde ER, Fauser BC, Bancsi LF, de Jong $\mathrm{FH}$, et al. Serum anti-Mullerian hormone levels: a novel measure of ovarian reserve. Hum Reprod. 2002 Dec;17(12):3065-71.

5. Muttukrishna S, Suharjono H, McGarrigle H, Sathanandan M. Inhibin
B and anti-Mullerian hormone: markers of ovarian response in IVF/ICSI patients? Bjog. 2004 Nov;111(11):1248-53.

6. Hazout A, Bouchard P, Seifer DB, Aussage P, Junca AM, Cohen-Bacrie P. Serum antimullerian hormone/mullerian-inhibiting substance appears to be a more discriminatory marker of assisted reproductive technology outcome than follicle-stimulating hormone, inhibin B, or estradiol. Fertil Steril. [Comparative Study]. 2004 Nov;82(5):1323-9.

7. Mantzavinos SD, Vlahos NP, Rizos D, Botsis D, Sergentanis TN, Deligeoroglou E, et al. Correlation of serum anti-Mullerian hormone levels with positive in vitro fertilization outcome using a short agonist protocol. Hormones (Athens). 2017 Apr;16(2):161-70.

8. La Marca A, Giulini S, Tirelli A, Bertucci E, Marsella T, Xella S, et al. Anti-Mullerian hormone measurement on any day of the menstrual cycle strongly predicts ovarian response in assisted reproductive technology. Hum Reprod. 2007 Mar;22(3):766-71. 
Web Site: https://jmed.utq.edu.iq

9. Knez J, Kovacic B, Medved M, Vlaisavljevic V. What is the value of anti-Mullerian hormone in predicting the response to ovarian stimulation with GnRH agonist and antagonist protocols? Reprod Biol Endocrinol. [Research Support, Non-U.S. Gov't]. 2015 Jun 10;13:58.

10. La Marca A, Stabile G, Artenisio AC, Volpe A. Serum antiMullerian hormone throughout the human menstrual cycle. Hum Reprod. 2006 Dec;21(12):3103-7.

11. Amanvermez R, Tosun M. An Update on Ovarian Aging and Ovarian Reserve Tests. Int J Fertil Steril. [Review]. 2016 JanMar;9(4):411-5.

12. Mutlu MF, Erdem A. Evaluation of ovarian reserve in infertile patients. J Turk Ger Gynecol Assoc. 2012;13(3):196-203.

13. Jirge PR. Ovarian reserve tests. J Hum Reprod Sci. 2011 Sep;4(3):108-13.

14. Ragni G, Chiaffarino F, Scarduelli C, Bonetti S, Nicolosi AE, Arnoldi $\mathrm{M}$, et al. The clomiphene citrate challenge test (CCCT) in women with elevated basal FSH: biological significance and predictive value. Eur J Obstet Gynecol Reprod Biol. [Evaluation Studies]. 2008 Nov;141(1):44-8.
15. Ravhon A, Lavery S, Michael S, Donaldson M, Margara R, Trew G, et al. Dynamic assays of inhibin $B$ and oestradiol following buserelin acetate administration as predictors of ovarian response in IVF. Hum Reprod. 2000 Nov;15(11):2297301.

16. Fanchin R, Schonauer LM, Righini C, Frydman N, Frydman R, Taieb J. Serum anti-Mullerian hormone dynamics during controlled ovarian hyperstimulation. Hum Reprod. 2003 Feb;18(2):328-32.

17. Eldar-Geva T, Ben-Chetrit A, Spitz IM, Rabinowitz R, Markowitz E, Mimoni T, et al. Dynamic assays of inhibin B, anti-Mullerian hormone and estradiol following FSH stimulation and ovarian ultrasonography as predictors of IVF outcome. Hum Reprod. 2005 Nov;20(11):3178-83.

18. Catteau-Jonard S, Pigny P, Reyss AC, Decanter C, Poncelet E, Dewailly D. Changes in serum antimullerian hormone level during lowdose recombinant follicular-stimulating hormone therapy for anovulation in polycystic ovary syndrome. J Clin Endocrinol Metab. [Research Support, Non-U.S. Gov't]. 2007 Nov;92(11):4138-43.

19. Fanchin R, Mendez Lozano DH, Louafi N, Achour-Frydman N, Frydman R, Taieb J. Dynamics of serum anti-Mullerian hormone levels during the luteal phase of controlled 
ovarian hyperstimulation. Hum

Reprod. 2005 Mar;20(3):747-51.

20. Weintraub A, Margalioth EJ, Chetrit AB, Gal M, Goldberg D, Alerhand $\mathrm{S}$, et al. The dynamics of serum anti-Mullerian-hormone levels during controlled ovarian hyperstimulation with GnRHantagonist short protocol in polycystic ovary syndrome and low responders. Eur J Obstet Gynecol Reprod Biol. 2014 May;176:163-7.

21. Elgindy EA, El-Haieg DO, El-Sebaey A. Anti-Mullerian hormone: correlation of early follicular, ovulatory and midluteal levels with ovarian response and cycle outcome in intracytoplasmic sperm injection patients. Fertil Steril. 2008 Jun;89(6):1670-6.

22. Penarrubia J, Fabregues F, Manau D, Creus M, Casals G, Casamitjana $\mathrm{R}$, et al. Basal and stimulation day 5 anti-Mullerian hormone serum concentrations as predictors of ovarian response and pregnancy in assisted reproductive technology cycles stimulated with gonadotropin-releasing hormone agonist--gonadotropin treatment. Hum Reprod. [Clinical Trial Randomized Controlled Trial Research Support, Non-U.S. Gov't]. 2005 Apr;20(4):91522.

23. Silberstein $\mathrm{T}$, MacLaughlin DT, Shai I, Trimarchi JR, LambertMesserlian G, Seifer DB, et al. Mullerian inhibiting substance levels at the time of HCG administration in IVF cycles predict both ovarian reserve and embryo morphology. Hum Reprod. 2006 Jan;21(1):159-63. 
Thi-Qar Medical Journal (TQMJ): Vol.(15), No.(1), 2018

Web Site: https://jmed.utq.edu.iq Email:utjmed@utq.edu.iq

\title{
قدرة التنبؤ للقياسات المتتابعة لهرمون ضد المولاري خلال الاخصاب الخارجي
}

\author{
المدرس الدكتور سامان حسين نوري
}

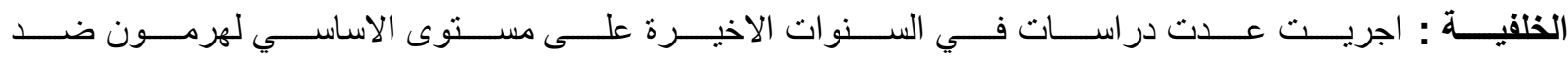

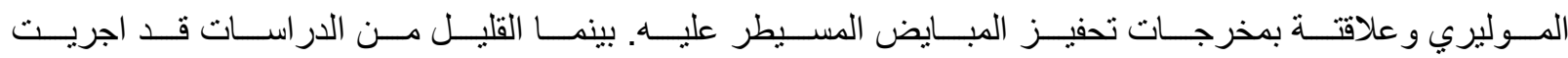

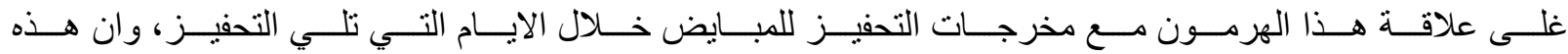

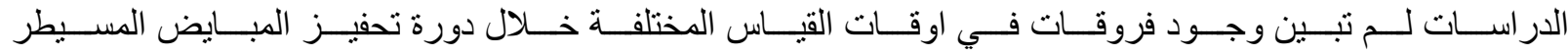
عليه.

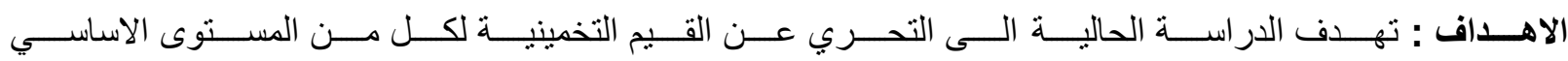
وامتسلسل بعد التحفيز لهرمون ضد المو لاري خلال فترة التحفيز للمبايض.

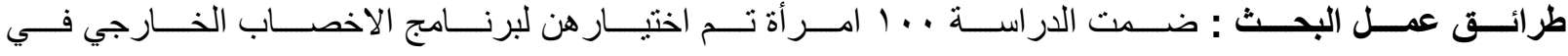

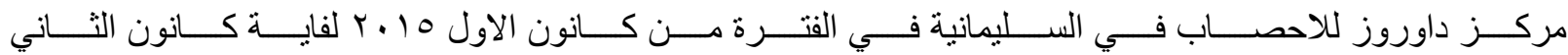

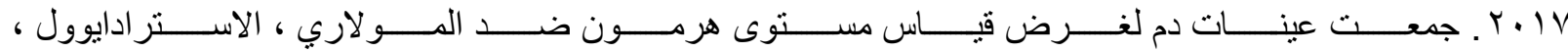

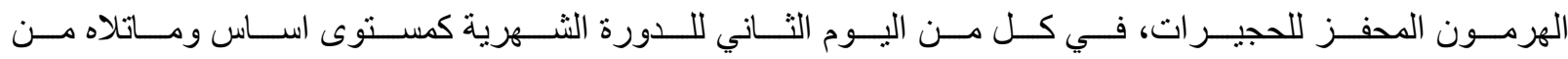

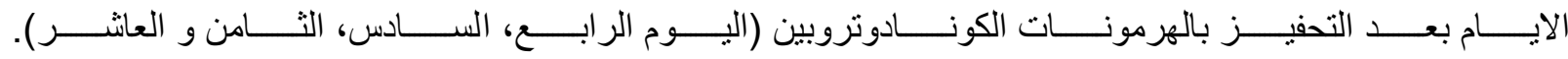

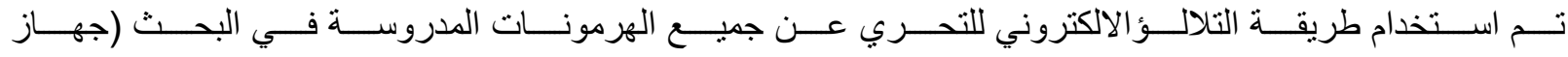

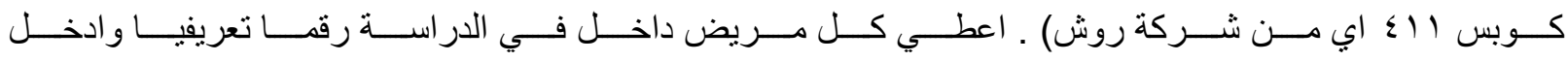

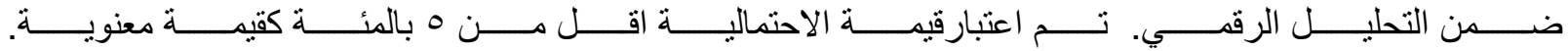

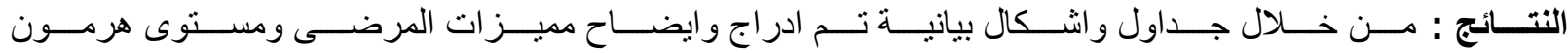

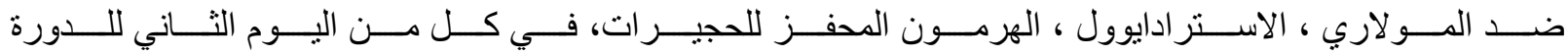

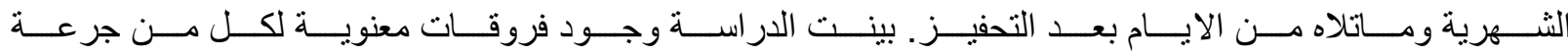

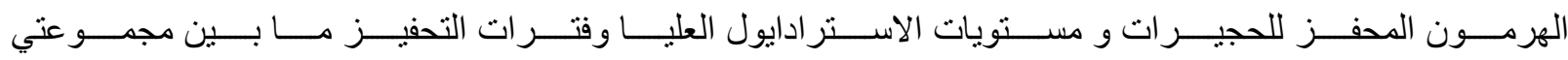

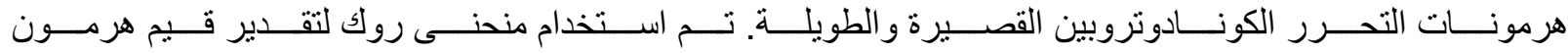

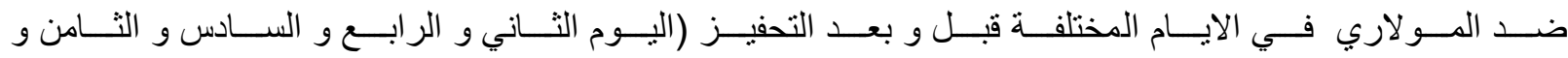

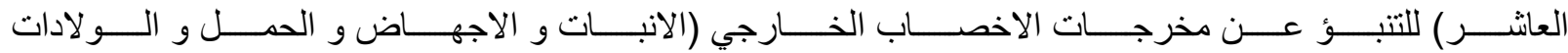

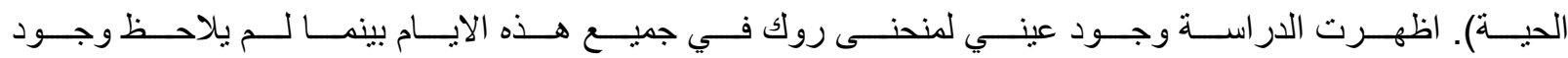
فروقات عينية لمستوى الهرمون عند مقارنة منحنى روك في فيما بينها. 
Thi-Qar Medical Journal (TQMJ): Vol.(15), No.(1), 2018

Web Site: https://jmed.utq.edu.iq $\quad$ Email:utjmed@utq.edu.iq

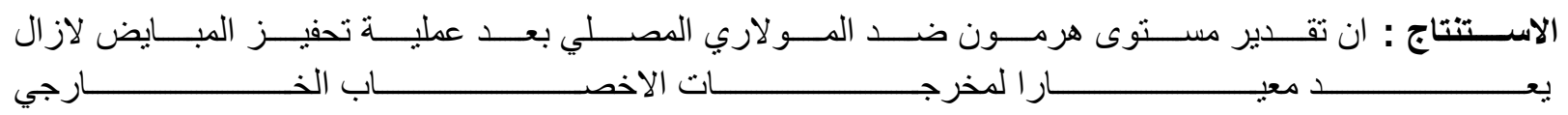

